\title{
Rapid Synthesis of Flavor Compound 4-Ethyloctanoic Acid under Microwave Irradiation
}

\author{
Yu-Ping Liu ${ }^{1,2}$, De-Cai Yin ${ }^{2}$, Hai-Tao Chen ${ }^{2}$ and Bao-Guo Sun ${ }^{1,2, *}$
}

1 College of Chemistry and Chemical Engineering, Shaanxi University of Science and Technology, Xi'an 710021, China

2 School of Chemical and Environmental Engineering, Beijing Technology and Business University, Beijing 100048, China; E-Mails: liuyp@th.btbu.edu.cn (Y.-P.L.); ydc8511276@163.com (D.-C.Y.); chenht@th.btbu.edu.cn (H.-T.C.)

* Author to whom correspondence should be addressed; E-Mail: sunbg @btbu.edu.cn;

Tel.: +86-010-689-847-68; Fax: +86-010-689-847-68.

Received: 30 September 2010; in revised form: 20 October 2010 / Accepted: 21 October 2010 /

Published: 25 October 2010

\begin{abstract}
Rapid synthesis of 4-ethyloctanoic acid by means of microwave irradiation is described. Diethyl malonate reacted with 2-ethyl-1-bromohexane in the presence of sodium ethoxide to give diethyl (2-ethylhexyl)malonate (1b). 1b was saponified in the solution of ethanol and potassium hydroxide and then acidified to form (2-ethylhexyl)propanedioic acid (1c), and 1c was heated and decarboxylized to give 4-ethyloctanoic acid (1d). The influence of reaction temperature and reaction time on the yield of $\mathbf{1 b}$ and the effect of reaction time on the yield of $\mathbf{1 c}$ and $\mathbf{1 d}$ were investigated in order to optimize the synthetic conditions. The relative optimal conditions for the synthesis of $\mathbf{1 b}$ were a mole ratio of sodium to diethyl malonate to 2-ethylhexyl bromide of 0.1:0.11:0.11, a reaction temperature of $80-85^{\circ} \mathrm{C}$, and a reaction time of $2-2.5 \mathrm{~h}$. The yield of $\mathbf{1 b}$ was about $79 \%$. 1b was saponified for $30 \mathrm{~min}$ and then acidified to form 1c, and the yield of 1c was $96 \%$. 1c was heated for $16 \mathrm{~min}$ at $180^{\circ} \mathrm{C}$ to give $1 \mathbf{d}$, and the yield of $1 \mathbf{d}$ was about $90 \%$. The overall yield of $\mathbf{1 d}$ is $70 \%$ under microwave irradiation. The reaction time was reduced greatly. In order to compare the result of microwave irradiation with that of an oil bath, the reactions were also performed in an oil bath. The structures of intermediates, product and by-product were confirmed by HRMS, ${ }^{1} \mathrm{H}$ NMR, ${ }^{13} \mathrm{C}-\mathrm{NMR}$ and IR.
\end{abstract}


Keywords: 4-ethyloctanoic acid; microwave irradiation; diethyl malonate; diethyl (2-ethylhexyl)malonate; (2-ethylhexyl)propanedioic acid

\section{Introduction}

4-Ethyloctanoic acid was first isolated from the root oil of the Costus plant (Saussurea lappa Clarke) by de Rijke [1]. In addition to costus root oil, 4-Ethyloctanoic acid also occurs in flue-cured virginia tobacco [2], aged Italian cheese [3], sheep cheese [4], goat cheese [5,6] and stewed beef gravy [7]. 4-Ethyloctanoic acid has waxy, fatty, creamy, moldy, sour sweaty, cheesy odor with animal-like nuances [8] and has been generally recognized as safe (GRAS) flavoring compounds (FEMA No. 3800) and as food additive in USA and China. It can be used for formulating food flavorings and added in meat products, soups, snack foods, milk products, hard candy, and chewing gum to improve their odors [9]. As raw material, 4-ethyloctanoic acid can be used for synthesizing new ester flavor compounds, such as 3-(methylthio)propyl-4-ethyloctanoate, 2-methyl-3-furanthiol-4-ethyloctanoate, 2-furanmethanethiol-4-ethyloctanoate, 4-methyl-5-thiazoleethanol-4-ethyloctanoate [10].

4-Ethyloctanoic acid can be synthesized by several methods. One method is that of S. G. Powell's from 2-ethyl-1-bromohexane and diethyl malonate [11] (Scheme 1). This method offers the advantage of cheap and available materials with mild reaction conditions, but requires long reaction times [12-15]. The British patent route by Knoevenagel reaction [16] (Scheme 2) offers a shorter reaction, but uses more expensive materials. The first step took 20 hours with a $50 \%$ yield of $\mathbf{2} \mathbf{b}$; the second step required platinum oxide to conduct catalytic hydroprocessing under strict operational conditions with an overall yield of 4-ethyloctanoic acid of about 45\%. A third method is the preparation of 4-ethyloctanoic acid by using cyano group activation [17] (Scheme 3); these starting materials are not readily available, but an overall yield of 4-ethyloctanoic acid was about $49 \%$, so while this method may be used in small-scale laboratory syntheses and it is not suitable on a larger scale or in a manufacturing plant. The fourth method is the synthesis of 4-ethyloctanoic acid by coupling reaction [18] (Scheme 4). This method includes more steps and complex operational conditions. For example, the coupling reaction requires anhydrous conditions and low temperatures $\left(-70{ }^{\circ} \mathrm{C}\right)$, so this method is only suitable for laboratory syntheses.

Microwave irradiation has attracted scientists' attention as a powerful tool for rapid, green and efficient synthesis of a variety of compounds [19,20] including synthesis of some FEMA-GRAS approved flavoring agents [21-24]. In view of the advantages and disadvantages of the four synthetic methods, we followed S. G. Powell's method under microwave irradiation. The aim of the work was to optimize the reaction conditions of each step and supply useful data for a one pot reaction. We also investigated the degree of influence of microwave irradiation on the three chemical reactions. The reaction time was shortened greatly and demonstrating microwave irradiation had the most obvious effect on the alkylation reaction. The reaction conditions of the synthetic steps were optimized in this work. 
Scheme 1. S. G. Powell's method.<smiles>CCCCC(CCCCCC(CCCCC(CC)CC)C(=O)OCC)CC(=O)OCC</smiles><smiles>CCCC(CC)CC(CCCC(CC)CCC(=O)O)C(=O)O</smiles>

Scheme 2. British patent route.

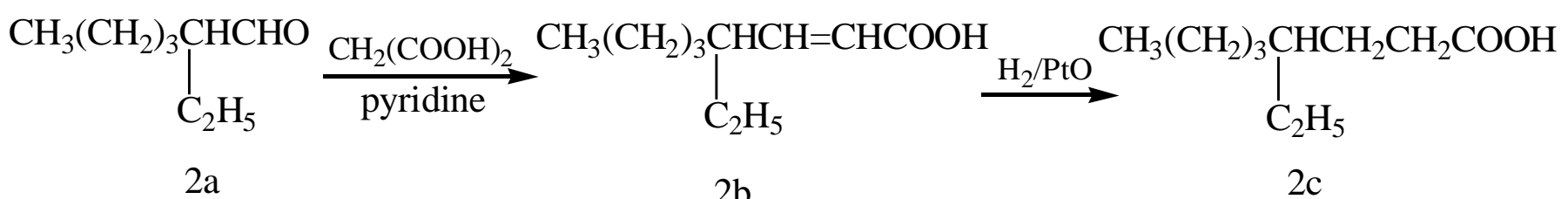

Scheme 3. Synthesis by cyano group activation.

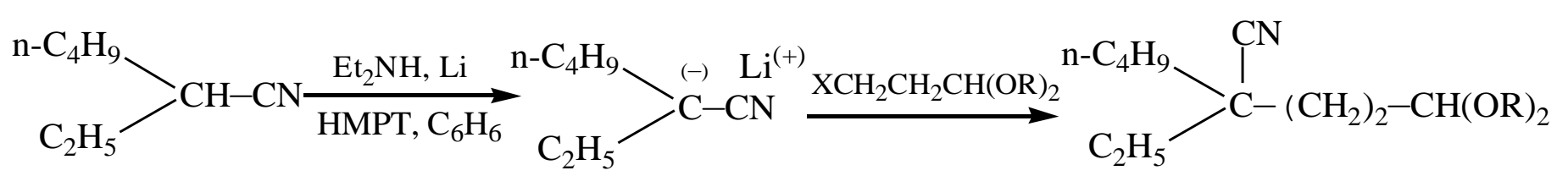

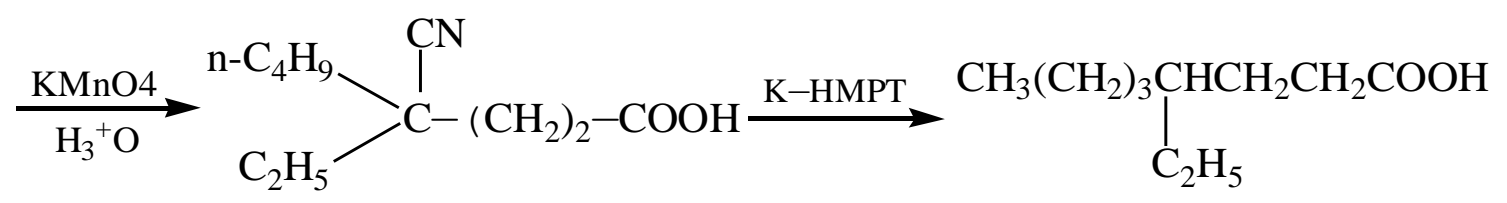

Scheme 4. Synthesis by coupling reaction.<smiles>CCCCC(CC)CCC(=O)OCC(=O)OC1CC(CC)CCC1=O</smiles> 


\section{Results and Discussion}

\subsection{The Optimization of Synthesis Conditions of Diethyl (2-Ethylhexyl)malonate (1b)}

We investigated the influences of mole ratio of starting materials, reaction temperature and reaction time on the yield of $\mathbf{1 b}$ to optimize synthesis conditions. Different mole ratios of starting materials were used under the same operational conditions and the results are shown in Table 1. As the ratio of sodium to diethyl malonate increased, the yield of $\mathbf{1 b}$ decreased; as the ratio of 2-ethylhexyl bromide to diethyl malonate increased, the yield of $\mathbf{1 b}$ increased slightly. The reason was that excessive sodium increased the yield of by-product and decreased the yield of $\mathbf{1 b}$. The by-product was separated by column chromatography and confirmed as diethyl di(2-ethylhexyl)malonate by spectrographic analysis. The by-product was formed by alkylation of $\mathbf{1 b}$; excessive sodium resulted in the increase of the amount of sodium ethoxide, while sodium ethoxide deprotanated diethyl (2-ethylhexyl)malonate to form a carboanion, which subsequently reacted with 2-ethylhexyl bromide to yield the by-product, decreasing the yield of $\mathbf{1 b}$. The optimal mole ratio of sodium to diethyl malonate to 2-ethylhexyl bromide was 0.1:0.11:0.11.

Table 1. Influence of different mole ratio of materials on the yield.

\begin{tabular}{lcccc}
\hline Run & $\boldsymbol{n}_{\text {(sodium) }}$ & $\boldsymbol{n}_{\text {(diethyl malonate) }}$ & $\boldsymbol{n}_{\text {(2-ethylhexyl bromide) }}$ & Yield of 1b (\%) \\
\hline 1 & 0.105 & 0.105 & 0.1 & 78.1 \\
2 & 0.110 & 0.105 & 0.1 & 70.6 \\
3 & 0.110 & 0.110 & 0.1 & 77.3 \\
4 & 0.115 & 0.110 & 0.1 & 73.4 \\
5 & 0.1 & 0.105 & 0.105 & 76.1 \\
6 & 0.1 & 0.105 & 0.110 & 76.6 \\
7 & 0.1 & 0.110 & 0.110 & 78.7 \\
8 & 0.1 & 0.110 & 0.115 & 78.8 \\
\hline
\end{tabular}

Reaction conditions: reaction temperature, $80{ }^{\circ} \mathrm{C}$; reaction time, $24 \mathrm{~h}$ [12]; heating method, oil bath.

The effect of reaction temperature and reaction time on the yield of $\mathbf{1 b}$ under microwave irradiation was investigated. The reaction mixture was sampled and monitored via gas-chromatography at certain intervals. The main results are listed in Table 2. The results show that the higher the reaction temperature, the shorter the reaction time to reach the maximum concentration of $\mathbf{1 b}$. When the reaction temperature rose from $75{ }^{\circ} \mathrm{C}$ to $80{ }^{\circ} \mathrm{C}$, the yield of $\mathbf{1 b}$ increased from $73.3 \%$ to $79.1 \%$; however, when the reaction temperature rose from $85{ }^{\circ} \mathrm{C}$ to $90{ }^{\circ} \mathrm{C}$, the yield of $\mathbf{1 b}$ decreased from $78.2 \%$ to $72.8 \%$. One possible reason is the occurrence of a side reaction. With the rise of reaction temperature, both the rates of the main reaction and the side reaction rate increased, but not to the same extent; this made the yield of $\mathbf{1 b}$ increase first and then decrease. Under microwave irradiation, the optimal reaction temperature was $80-85{ }^{\circ} \mathrm{C}$, and the optimal reaction time was $2-2.5 \mathrm{~h}$. As a comparison, the experiments were performed using an oil bath and the results are shown in Table 3. The results show that when using an oil bath, the reaction takes much more time to reach the higher yield. 
Table 2. Effect of reaction temperature and reaction time on the yield.

\begin{tabular}{cccc}
\hline $\begin{array}{c}\text { Reaction temperature } \\
\left({ }^{\circ} \mathbf{C}\right)\end{array}$ & $\begin{array}{c}\text { Maximum concentration of } \\
\text { 1b in reaction mixture }(\boldsymbol{\%})\end{array}$ & $\begin{array}{c}\text { Reaction time } \\
(\mathbf{h})\end{array}$ & $\begin{array}{c}\text { Yield of 1b } \\
(\boldsymbol{\%})\end{array}$ \\
\hline 75 & 70.92 & 3.0 & 73.3 \\
80 & 76.37 & 2.5 & 79.1 \\
85 & 74.22 & 2.0 & 78.2 \\
90 & 70.53 & 1.5 & 72.8 \\
\hline
\end{tabular}

Reaction conditions: the mole ratio of sodium, diethyl malonate to 2-ethylhexyl bromide, 0.1:0.11:0.11; heating method, microwave irradiation.

Table 3. Effect of reaction time on the yield of $\mathbf{1 b}$ in an oil bath.

\begin{tabular}{ccccc}
\hline $\begin{array}{c}\text { Reaction time } \\
(\mathrm{h})\end{array}$ & 6 & 12 & 18 & 24 \\
\hline $\begin{array}{c}\text { Yield of } \mathbf{1 b} \\
(\%)\end{array}$ & 71.0 & 75.5 & 77.2 & 78.9 \\
\hline
\end{tabular}

Reaction conditions: the mole ratio of sodium, diethyl malonate to 2-ethylhexyl bromide, 0.1:0.11:0.11; heating method, oil bath; reaction temperature, $80{ }^{\circ} \mathrm{C}$.

The product $\mathbf{1 b}$ was analyzed by ${ }^{13} \mathrm{C}-\mathrm{NMR}$. Because $\mathbf{1 b}$ is derived from diethyl malonate, there is a symmetric group in the structure of $\mathbf{1 b}$, so there should be twelve signals visible in the ${ }^{13} \mathrm{C}-\mathrm{NMR}$ spectrum; however, there were eleven signals. A chemical shift of $\mathrm{C}_{8}$ was the same as that of $\mathrm{CH}_{3}$ from $\mathrm{OCH}_{2} \mathrm{CH}_{3}$, and the signal at 14.00 stood for two carbon atoms.

\subsection{The Optimization of Reaction Time of Synthesis of (2-Ethylhexyl)propanedioic Acid (1c)}

The reactions were carried out separately in an oil bath and under microwave irradiation in order to compare and optimize the reaction time for synthesis of 1c, and the results are listed in Table 4 . The results indicated that the reaction took a shorter time to reach the higher yield under microwave irritation. The appropriate reaction time for synthesis of $\mathbf{1 c}$ under microwave irradiation was $30 \mathrm{~min}$.

Table 4. Effect of reaction time on the yield of 1c.

\begin{tabular}{cccc}
\hline \multicolumn{2}{c}{ In oil bath } & \multicolumn{2}{c}{ Under microwave irradiation } \\
\hline $\begin{array}{c}\text { Reaction time } \\
(\mathbf{m i n})\end{array}$ & $\begin{array}{c}\text { Yield of 1c } \\
(\boldsymbol{\%})\end{array}$ & $\begin{array}{c}\text { Reaction time } \\
(\mathbf{m i n})\end{array}$ & $\begin{array}{c}\text { Yield of 1c } \\
(\boldsymbol{\%})\end{array}$ \\
\hline 60 & 93.0 & 5 & 94.3 \\
90 & 95.5 & 10 & 96.1 \\
120 & 95.9 & 20 & 97.4 \\
150 & 96.1 & 30 & 97.7 \\
\hline
\end{tabular}

Reaction conditions: the mole ratio of potassium hydroxide to diethyl 2-ethylhexyl-malonate (1b), 0.4:0.1; $1 \mathrm{~b}, 0.05 \mathrm{~mol}$; reaction temperature, $85^{\circ} \mathrm{C}$. 
When 1c was dissolved in absolute ethanol and subjected to gas chromatography to measure the concentration of $\mathbf{1 c}$, we found that $\mathbf{1 c}$ was decarboxylized to form $1 \mathbf{d}$ at $180{ }^{\circ} \mathrm{C}$. The result suggested that the reaction temperature for preparing $1 \mathbf{d}$ from $1 \mathbf{c}$ would be $180^{\circ} \mathrm{C}$.

\subsection{The Optimization of Reaction Time of Synthesis of 4-Ethyloctanoic Acid (1d)}

Because 1c was decarboxylized to form $1 \mathbf{d}$ at $180{ }^{\circ} \mathrm{C}$, it was not suitable to monitor the reaction via gas-chromatography; however, carbon dioxide is generated in the reaction, so the reaction procedure was monitored by measuring the reducing amount of reaction mixture. The reactions were performed separately using an oil bath and under microwave irradiation and the results are listed in Table 5.

The product obtained under microwave irradiation was slightly more than the product obtained using an oil bath, but there was little difference in reaction time, unlike the above reactions. The reason is that the polarity of $\mathbf{1 c}$ is weak and the reaction is not carried out in polar solvent to simplify the final treatment. The appropriate reaction time for synthesis of $\mathbf{1 d}$ under microwave irradiation was 16 min. After 1c was decarboxylized to form 1d, we found the chemical shift of carbon $(\mathrm{CH})$ connected with carboxyl group changed from 49.80 to 38.27 in the ${ }^{13} \mathrm{C}$-NMR spectrums.

Table 5. Effect of reaction time on the reaction.

\begin{tabular}{cccc}
\hline & In oil bath & \multicolumn{2}{c}{ Under microwave irradiation } \\
\hline $\begin{array}{c}\text { Reaction time } \\
(\mathbf{m i n})\end{array}$ & $\begin{array}{c}\text { The reducing amount of } \\
\text { reaction mixture }(\mathbf{g})\end{array}$ & $\begin{array}{c}\text { Reaction time } \\
(\mathbf{m i n})\end{array}$ & $\begin{array}{c}\text { The reducing amount } \\
\text { of reaction mixture }(\mathbf{g})\end{array}$ \\
\hline 5 & 4.186 & 4 & 4.679 \\
15 & 4.445 & 8 & 4.719 \\
30 & 4.536 & 12 & 4.746 \\
60 & 4.575 & 16 & 4.759 \\
\hline $\begin{array}{c}\text { Separated } \\
\text { yield of } \mathbf{1 d}(\%)\end{array}$ & 87.0 & Separated & 90.6 \\
\hline
\end{tabular}

Reaction conditions: reaction temperature, $180{ }^{\circ} \mathrm{C} ; \mathbf{1 c}, 0.1 \mathrm{~mol}(21.6 \mathrm{~g})$.

The total yields of 4-ethyloctanoic acid on oil bath and under microwave irradiation were calculated; they were $66 \%(78.9 \% \times 96.1 \% \times 87.0 \%)$ and $70 \%(79.1 \% \times 97.7 \% \times 90.6 \%)$. The reactions took more time when using an oil bath; the three steps needed separately $24 \mathrm{~h}, 150 \mathrm{~min}$ and $60 \mathrm{~min}$. However, the three steps needed just $2.5 \mathrm{~h}, 30 \mathrm{~min}$ and $16 \mathrm{~min}$ under microwave irradiation.

\section{Experimental Section}

\subsection{General}

Sodium, anhydrous ethanol, diethyl malonate, potassium hydroxide, hydrochloric acid (36.5\%), ethyl ether and sodium sulfate (anhydrous) were obtained from Sinopharm Chemical Reagent Beijing Co., Ltd. (Beijing, China). 2-Ethylhexyl bromide was obtained from Jiangsu WDL Chemical Co., Ltd. (Jiangsu, China).

The contents were determined on a Varian CP3800 gas chromatograph. High-resolution mass spectra were obtained at a Bruker Apex IV Fourier-Transform Mass Spectrometry in Peking University. 
${ }^{1} \mathrm{H}-\mathrm{NMR}$ and ${ }^{13} \mathrm{C}$-NMR spectra were recorded on a Bruker DRX-300 nuclear magnetic resonance spectrometer. IR spectra were measured on a Nicolet Avater 370 Fourier transform infrared spectrometer. The reactor was a XH-300A xianghao microwave reactor.

\subsection{Synthesis of Diethyl (2-Ethylhexyl)malonate (1b)}

Sodium (2.3 g, $0.1 \mathrm{~mol}$ ) was dissolved in $40 \mathrm{ml}$ anhydrous ethanol and diethyl malonate (17.62 $\mathrm{g}$, $0.11 \mathrm{~mol}$ ) was added during agitation. While the resulting mixture was under microwave irradiation, 2-ethylhexyl bromide $(21.24 \mathrm{~g}, 0.11 \mathrm{~mol})$ was added dropwise over the course of $10 \mathrm{~min}$ then the reaction mixture was refluxed for 2.5 hours at $80{ }^{\circ} \mathrm{C}$. At the end of reflux, ethanol in the reaction mixture was distilled off and the sample was washed with saturated $\mathrm{NaCl}$ aqueous solution. The organic layer was separated, and the aqueous layer was extracted with ethyl ether. The organic layer and the ethyl ether extraction were mixed together, washed with brine, dried with anhydrous $\mathrm{NaSO}_{4}$ and filtered to remove solids. After the ethyl ether was evaporated off in vacuo, the mixture was weighed, and the content of $\mathbf{1 b}$ in the mixture was determined by gas-chromatography. The product was further purified using distillation under the reduced pressure. B.p. $140{ }^{\circ} \mathrm{C} / 0.8 \mathrm{KPa}, \mathrm{HRMS}\left(\mathrm{ESI}^{+}\right)$ $\mathrm{m} / \mathrm{z}$ calcd. for $\mathrm{C}_{15} \mathrm{H}_{29} \mathrm{O}_{4}[\mathrm{M}+\mathrm{H}]^{+} 273.20604$, found 273.20589 , calcd. for $\mathrm{C}_{15} \mathrm{H}_{28} \mathrm{O}_{4} \mathrm{Na}[\mathrm{M}+\mathrm{Na}]^{+}$ 295.18798, found 295.18776. ${ }^{1} \mathrm{H}$ NMR (300 $\left.\mathrm{MHz}, \mathrm{CDCl}_{3}, \delta \mathrm{ppm}\right)$ 4.16-4.22 (m, 4H), $3.41(\mathrm{t}, 1 \mathrm{H}), 1.82-1.86(\mathrm{~m}, 2 \mathrm{H}), 1.25-1.35(\mathrm{~m}, 15 \mathrm{H}), 0.83-0.90(\mathrm{~m}, 6 \mathrm{H}) .{ }^{13} \mathrm{C}-\mathrm{NMR}\left(300 \mathrm{MHz}, \mathrm{CDCl}_{3}\right.$, $\delta$ ppm) $169.72(\mathrm{C}=\mathrm{O}), 61.15\left(\mathrm{OCH}_{2}\right), 50.04(\mathrm{CH}), 36.71(\mathrm{CH}), 32.48\left(\mathrm{CH}_{2}\right), 32.35\left(\mathrm{CH}_{2}\right), 28.50\left(\mathrm{CH}_{2}\right)$, $25.45\left(\mathrm{CH}_{2}\right), 22.91\left(\mathrm{CH}_{2}\right), 14.00\left(2 \mathrm{CH}_{3}\right), 10.37\left(\mathrm{CH}_{3}\right) . \mathrm{IR}\left(\mathrm{KBr}, \mathrm{cm}^{-1}\right) 2961,2931,2874,1735,1464$, $1368,1176,1150,1032$.

\subsection{The Isolation of By-Product (Diethyl Di(2-ethylhexyl)malonate) from the Distill Remainder of $\mathbf{1 b}$}

After the 1b was distilled off, the remaining sample was cooled and subjected to a column chromatographic separation using silica gel and $2 \%$ petroleum ether in ethyl acetate. The fractions collected were monitored by thin layer chromatography. The "best" fractions were mixed together, the petroleum ether and ethyl acetate were removed under the reduced pressure, and the purified by-product was obtained as a yellow and transparent liquid. HRMS(ESI ${ }^{+}$) m/z calcd. for $\mathrm{C}_{23} \mathrm{H}_{44} \mathrm{O}_{4} \mathrm{Na}$ $[\mathrm{M}+\mathrm{Na}]^{+}$407.31318, found 407.31350. ${ }^{1} \mathrm{H}-\mathrm{NMR}\left(300 \mathrm{MHz}, \mathrm{CDCl}_{3}, \delta \mathrm{ppm}\right)$ 4.09-4.16 (t, 2H), $1.87-1.89(\mathrm{~m}, 2 \mathrm{H}), 1.19-1.26(\mathrm{~m}, 12 \mathrm{H}), 0.77-0.89(\mathrm{~m}, 6 \mathrm{H}) ;{ }^{13} \mathrm{C}-\mathrm{NMR}\left(\mathrm{CDCl}_{3}, \delta \mathrm{ppm}\right) 172.79(\mathrm{C}=\mathrm{O})$, $60.84\left(\mathrm{OCH}_{2}\right), 56.09(\mathrm{CH}), 36.62(\mathrm{CH}), 34.04\left(\mathrm{CH}_{2}\right), 33.02\left(\mathrm{CH}_{2}\right), 28.29\left(\mathrm{CH}_{2}\right), 25.87\left(\mathrm{CH}_{2}\right)$, $23.09\left(\mathrm{CH}_{2}\right), 14.10\left(\mathrm{CH}_{3}\right), 13.90\left(\mathrm{CH}_{3}\right), 10.10\left(\mathrm{CH}_{3}\right) . \mathrm{IR}\left(\mathrm{KBr}, \mathrm{cm}^{-1}\right) 2958,2929,2874,1731,1464$, $1179,1380,860,727,558$.

\subsection{Synthesis of (2-Ethylhexyl)propanedioic Acid (1c)}

Diethyl (2-ethylhexyl)malonate (0.05 mol, $13.6 \mathrm{~g}$ ) was added to a solution of $\mathrm{KOH}(11.2 \mathrm{~g}, 0.2 \mathrm{~mol})$ in ethanol (40 $\mathrm{mL} \mathrm{95 \% ).} \mathrm{Under} \mathrm{microwave} \mathrm{irradiation,} \mathrm{the} \mathrm{reaction} \mathrm{mixture} \mathrm{was} \mathrm{refluxed} \mathrm{for} 0.5$ hour, and then most of ethanol was distilled off and water $(100 \mathrm{~mL})$ was added. The resulting mixture was acidified with $\mathrm{HCl}$ (conc.) and the organic layer was separated. The water phase was extracted with ethyl ether. The organic phase and extracts were combined, washed with water and brine, dried with anhydrous $\mathrm{NaSO}_{4}$ and filtered to remove solids. After evaporation of the ethyl ether, 
2-ethylhexylpropanedioic acid was obtained. M.p. 100.5-101.0 ${ }^{\circ} \mathrm{C}$, HRMS $\left(\mathrm{ESI}^{+}\right) \mathrm{m} / \mathrm{z}$ calcd. for $\mathrm{C}_{11} \mathrm{H}_{20} \mathrm{O}_{4} \mathrm{Na}[\mathrm{M}+\mathrm{Na}]^{+}$239.12538, found 239.12536. ${ }^{1} \mathrm{H} \mathrm{NMR}\left(300 \mathrm{MHz}, \mathrm{CDCl}_{3}, \delta \mathrm{ppm}\right) 11.90(\mathrm{~s}$, 2H), 3.51-3.56 (t, 1H), $1.90(\mathrm{~m}, 2 \mathrm{H}), 1.26-1.35(\mathrm{~m}, 9 \mathrm{H}), 0.84-0.91(\mathrm{~m}, 6 \mathrm{H}) .{ }^{13} \mathrm{C}-\mathrm{NMR}(300 \mathrm{MHz}$, $\left.\mathrm{CDCl}_{3}, \delta \mathrm{ppm}\right) 175.86(\mathrm{COOH}), 49.80(\mathrm{CH}), 36.64(\mathrm{CH}), 32.49\left(\mathrm{CH}_{2}\right), 32.20\left(\mathrm{CH}_{2}\right), 28.32\left(\mathrm{CH}_{2}\right)$, $25.33\left(\mathrm{CH}_{2}\right), 22.96\left(\mathrm{CH}_{2}\right), 14.02\left(\mathrm{CH}_{3}\right), 10.26\left(\mathrm{CH}_{3}\right) . \mathrm{IR}\left(\mathrm{KBr}, \mathrm{cm}^{-1}\right)$ 3435, 3006, 2916, 2859, 1604, $1525,1394,1374,1270,1129,929$.

\subsection{Synthesis of 4-Ethyloctanoic Acid (1d)}

Under microwave irradiation, (2-ethylhexyl)propanedioic acid (21.6 g, $0.1 \mathrm{~mol}$ ) was heated for $16 \mathrm{~min}$ at $180{ }^{\circ} \mathrm{C}$. The resulting mixture was evaporated in vacuo to collect the distillate at $123{ }^{\circ} \mathrm{C} / 0.5 \mathrm{KPa}$ and obtain 4-ethyloctanoic acid. HRMS $\left(\mathrm{ESI}^{+}\right) \mathrm{m} / \mathrm{z}$ calcd. for $\mathrm{C}_{10} \mathrm{H}_{19} \mathrm{O}_{2}[\mathrm{M}-\mathrm{H}]^{+}$ 171.13905, found 171.13894. ${ }^{1} \mathrm{H}$ NMR $\left(300 \mathrm{MHz}, \mathrm{CDCl}_{3}, \delta \mathrm{ppm}\right) 11.67(\mathrm{~s}, 1 \mathrm{H}), 2.30-2.36(\mathrm{~m}, 2 \mathrm{H})$, 1.60-1.62 (m, 2H), 1.25-1.31 (m, 9H), 0.87-0.91 (m, 6H). ${ }^{13} \mathrm{C}-\mathrm{NMR}\left(300 \mathrm{MHz}, \mathrm{CDCl}_{3}, \delta \mathrm{ppm}\right)$ $181.05(\mathrm{COOH}), 38.27(\mathrm{CH}), 32.39\left(\mathrm{CH}_{2}\right), 31.60\left(\mathrm{CH}_{2}\right), 28.72\left(\mathrm{CH}_{2}\right), 27.92\left(\mathrm{CH}_{2}\right), 25.48\left(\mathrm{CH}_{2}\right), 23.04$ $\left(\mathrm{CH}_{2}\right), 14.07\left(\mathrm{CH}_{3}\right), 10.65\left(\mathrm{CH}_{3}\right) . \mathrm{IR}\left(\mathrm{KBr}, \mathrm{cm}^{-1}\right)$ 3300-2500, 2960, 2929, 2873, 1711, 1459, 1413, 1380, 1292, 935.

\section{Conclusions}

4-Ethyloctanoic acid was synthesized starting from diethyl malonate through alkylation, saponification, acidification and decarboxylation under microwave irradiation. The reaction of diethyl malonate with 2-ethylhexyl bromide gave diethyl (2-ethylhexyl)malonate in about 79\% yield. Diethyl (2-ethylhexyl)malonate was saponified and acidified to form (2-ethylhexyl)propanedioic acid in about 96\% yield. (2-Ethylhexyl)propanedioic acid was heated and decarboxylized to give 4-ethyloctanoic acid in about $90 \%$ yield. The overall yield of 4-ethyloctanoic acid is $70 \%$. This method provides a simple, rapid and eco-friendly synthesis of 4-ethyloctanoic acid.

\section{Acknowledgements}

The project was supported by Beijing Municipal Party Committee Organization Department (No: 20081D0500300127).

\section{References}

1. Rijke, D.D.; Traas, P.C.; Heide, R.T. Acidic components in essential oils of costus root, patchouli and olibanum. Phytochemistry 1978, 17, 1664-1666.

2. Anderson, R.C.; Kelly, A.G. Identification of a low flavor threshold carboxylic acid constituent, 4-ethyloctanoic acid, in flue-cured Virginia tobacco. J. Agric. Food Chem. 1988, 36, 353-354.

3. Ha, J.K.; Lindsay, R.C. Volatile branched-chain fatty acids and phenolic compounds in aged Italian cheesw flavors. J. Food Sci. 1991, 56, 1241-1247.

4. Ha, J.K.; Lindsay, R.C. Contribution of cow, sheep, and goat milks to characterizing branchedchain fatty acid and phenolic flavors in varietal cheeses. J. Dairy Sci. 1991, 74, 3267-3274. 
5. Salles, C.; Sommerer, N.; Septier, C. Goat cheese flavor: Sensory evaluation of branched-chain fatty acids and small peptides. J. Food Sci. 2002, 67, 835-841.

6. Carunchia-Whetstine, M.E.; Karagul-Yuceer, Y.; Avsar, Y.K. Identification andquantification of character aroma components in fresh chevre-style goat cheese. J. Food Sci. 2003, 68, 2441-2447.

7. Christlbauer, M.; Schieberle, P. Characterization of the key aroma compounds in beef and pork vegetable gravies á la chef by application of the aroma extract dilution analysis. J. Agric. Food Chem. 2009, 57, 9114-9122.

8. Mosciano, G. Organoleptic characteristics of flavor materials. Perfum. Flavor. 2007, 32, 16-18.

9. Oser, B.L.; Ford, R.A. GRAS flavoring Substances 17. Food Tech. 1996, 50, 78-80.

10. Liu, Y.; Chen, H.; Yin, D.; Sun, B. Synthesis and odor evaluation of five new sulfur-containing ester flavor compounds from 4-ethyloctanoic acid. Molecules 2010, 15, 5104-5111.

11. Powell, S.G.; Baldwin, M.M. The condensation of 2-butanone with aldehydes of the type RR ${ }^{1}$ CHCHO. J. Am. Chem. Soc. 1936, 58, 1871-1872.

12. Keil, W. The fat from fatty acids with odd numbers of carbon atoms. III. Z. Physiol. Chem. 1942, $274,175-185$.

13. Petrov, A.D.; Nikishin, G.I.; Ogibin, Y.N. The synthesis and surface-active properties of branched chain acids of the series, $\mathrm{C}_{\mathrm{n}} \mathrm{H}_{2 \mathrm{n}+1} \mathrm{COOH}$, with a $\mathrm{C}$ chain, C10-C20. Vses. Nauchn.-Issled. Inst. Zhirov 1960, 20, 278-292.

14. Dziomko, V.M.; Dunaevskaya, K.A. Synthesis of some aliphatic ketones with branched chains and different distance of branches from oxo group. Tr. Vses. Nauch. Issled. Inst. 1966, 28, 184-192.

15. Hedenstrom, E.; Nguyen, B.V.; Silks, L.A. Do enzymes recognize remotely located stereocentres? Highly enantioselective Candida rugosa lipase-catalysed esterification of the 2- to 8-methyldecanoic acids. Tetrahedron Asymmetry 2002, 13, 835-844.

16. Neth, N.V. Naarden International. Branched-chain carboxylic acids as perfume components. $G B$ Patent 1,503,241, 8 March 1978.

17. Larcheveque, M.; Cuvigny, T. A new preparation of $\beta$ and $\gamma$-alkyl aldehydes or acids by using activating cyano group. Tetrahedron Lett. 1975, 44, 3851-3854.

18. Sugiyama, T.; Sasada, H.; Masaki, J.; Yamashita, K. Unusual fatty acids with specific odor from mature male goat. Agric. Boil. Chem. 1981, 45, 2655-2658.

19. Srivastava, K.P.; Mishra, P.K. Green syntheses of 4-substitued-3-phenyl sydnones under microwave irradiation. Int. J. Pure Appl. Chem. 2008, 3, 171-174.

20. Reyes, L.; Corona, S.; Arroyo, G. Eco-contribution for the production of $N$-arylnitrones: Solventfree and assisted by microwaves. Int. J. Mol. Sci. 2010, 11, 2576-2583.

21. Sinha, A.K.; Sharma, A.; Joshi, B.P. One-pot two-step synthesis of 4-vinylphenols from 4-hydroxy substituted benzaldehydes under microwave irradiation: A new perspective on the classical Knoevenagel-Doebner reaction. Tetrahedron 2007, 63, 960-965.

22. Nomura, E.; Hosoda, A.; Mori, H.; Taniguchi, H. Rapid base-catalyzed decarboxylation and amide-forming reaction of substituted cinnamic acids via microwave heating. Green Chem. 2005, 7, 863-866. 
23. Sharma, A.; Kumar, R.; Sharma, N.; Sinha, A.K. Unique versatility of ionic liquids as clean decarboxylation catalyst cum solvent: A metal- and quinoline-free paradigm towards synthesis of indoles, styrenes, stilbenes and arene derivatives under microwave irradiation in aqueous conditions. Adv. Synth. Catal. 2008, 350, 2910-2920.

24. Sinha, A.K.; Joshi, B.P.; Sharma, A. Microwave induced process for the preparation of substituted 4-vinylphenols. US Patent 6,989,467, 24 January 2006.

(C) 2010 by the authors; licensee MDPI, Basel, Switzerland. This article is an open access article distributed under the terms and conditions of the Creative Commons Attribution license (http://creativecommons.org/licenses/by/3.0/). 